University of Nebraska - Lincoln

DigitalCommons@University of Nebraska - Lincoln

Agronomy \& Horticulture -- Faculty Publications

Agronomy and Horticulture Department

1987

\title{
Inheritance of Seedling Hydrocyanic Acid Potential and Seed Weight in Sorghum-Sudangrass Crosses
}

\author{
J. F. S. Lamb \\ Francis A. Haskins \\ University of Nebraska-Lincoln, fhaskins@neb.rr.com \\ H. J. Gorz \\ Kenneth P. Vogel \\ University of Nebraska-Lincoln, kvogel1@unl.edu
}

Follow this and additional works at: https://digitalcommons.unl.edu/agronomyfacpub

Part of the Plant Sciences Commons

Lamb, J. F. S.; Haskins, Francis A.; Gorz, H. J.; and Vogel, Kenneth P., "Inheritance of Seedling Hydrocyanic Acid Potential and Seed Weight in Sorghum-Sudangrass Crosses" (1987). Agronomy \& Horticulture -Faculty Publications. 288.

https://digitalcommons.unl.edu/agronomyfacpub/288

This Article is brought to you for free and open access by the Agronomy and Horticulture Department at DigitalCommons@University of Nebraska - Lincoln. It has been accepted for inclusion in Agronomy \& Horticulture -Faculty Publications by an authorized administrator of DigitalCommons@University of Nebraska - Lincoln. 


\title{
Inheritance of Seedling Hydrocyanic Acid Potential and Seed Weight in Sorghum-Sudangrass Crosses ${ }^{1}$
}

\author{
J. F. S. Lamb, F. A. Haskins, H. J. Gorz, and K. P. Voge ${ }^{2}$
}

\begin{abstract}
The hydrocyanic acid potential (HCN-p) of sorghum [Sorghum bicolor (L.) Moench] plants is recognized as a heritable trait, but previous studies on the mode of inheritance of $\mathrm{HCN}$-p have produced inconsistent results. The objective of this study was to investigate the inheritance patterns of seedling $\mathrm{HCN}$-p and also of seed weight in reciprocal crosses of sorghum and sudangrass [formerly $S$. sudanense (Piper) Stapf]. Both traits were found to be inherited quantitatively. Generation means analysis indicated that additive genetic effects were most important for both seed weight (53\% of variation) and seedling $\mathrm{HCN}-\mathrm{p}$ (74\% of variation). A maternal effect was found for both traits in the $F_{1}$ and backcross generations. No evidence of this reciprocal effect was found in the $F_{2}$, suggesting that cytoplasmic inheritance was not involved. A highly positive correlation between seed weight and HCN-p was found across all entries, across both parents, and in the $F_{1}$ and backcross generations. However, correlation coefficients between seed weight and seedling $\mathrm{HCN}$-p for individual entries, the pooled $F_{2}$ 's, or within types of seed parents in the $F_{1}$ or backcross generations were generally nonsignificant. It was concluded that seed weight per se does not have a large effect on seedling $\mathrm{HCN}$-p.
\end{abstract}

Additional index words: Dhurrin, Prussic acid, Sorghum bicolor (L.) Moench, S. sudanense (Piper) Stapf.

$\mathrm{P}$ REVIOUS studies of the inheritance of the cyanogenic glucoside, dhurrin [ $p$-hydroxy-(S)-mandelonitrile- $\beta$-D-glucoside], in sorghum [Sorghum bicolor (L.) Moench] have not yielded consistent results. Nass (17) in 1972 reviewed published reports on the inheritance of cyanogenesis in sorghum, various Lotus species, and white clover (Trifolium repens L.), and concluded that the situation in sorghum was more complex than that in other species. The studies agreed that the dhurrin content or hydrocyanic acid potential $(\mathrm{HCN}$ p) of sorghum leaves was a heritable trait, but disagreed on the presence or absence of dominance, dominance of high or low HCN-p, and the number of genes involved.

Krauss (14), in a study not included in Nass's review, concluded that $\mathrm{HCN}$-p was conditioned by four genes with additive effects without dominance. Other studies conducted since Nass's review reported different conclusions on the importance of additive and nonadditive effects $(2,4,9)$. Recently, Gorz et al. (10) found that seedlings of sorghum lines KS8 and N32 were high in $H C N-p$, but the HCN-p of flag leaves from field-grown plants of KS8 was only about $1 / 10$ as high as that of $\mathrm{N} 32$ flag leaves. A single gene pair was found to be primarily responsible for the large difference in mature leaves, and neither low nor high HCN-p was completely dominant. The lack of agree-

\footnotetext{
Contribution from the USDA-ARS and the Nebraska Agric. Res. Div., Lincoln, NE 68583. Published as Paper no. 8119, Journal Series, Nebraska Agric. Res. Div. Research was conducted under Project 12-114. Received 7 Aug. 1986.

${ }^{2}$ Former graduate research assistant, George Holmes professor of agronomy, and supervisory research geneticists, USDA-ARS, respectively.
}

Published in Crop Sci. 27:522-525 (1987). ment among these studies was no doubt due in part to differences in lines or cultivars used, conditions of growth, types of tissue assayed, and the analytical procedures used.

The primary objective of the present study was to investigate the inheritance of seedling HCN-p in crosses of grain sorghum and sudangrass [formerly $S$. sudanense (Piper) Stapf] lines. The sudangrass lines had been selected for low HCN-p; crosses of these lines to the high-HCN-p sorghum lines provided a wider range in HCN-p than was possible in most of the previous studies of HCN-p inheritance. Also, this study utilized the spectrophotometric assay described by Gorz et al. (8). This assay is independent of the activity of catabolic enzymes in the plant.

\section{MATERIALS AND METHODS}

Four inbred parental lines were used in this study. Two were lines from sudangrass populations, and two were grain sorghum cultivars. The two sudangrass lines, 81-1901-7 and 81-1904-74, hereafter referred to as 1901 and 1904, respectively, were selected primarily for low HCN-p. Both lines carried the $\mathrm{ms}_{3}$ gene for genetic male sterility (gms); this recessive gene caused 25 to $30 \%$ of the plants in each line to be sterile. Both sudangrass lines also restored fertility when crossed with cytoplasmic-male-sterile (cms) sorghum lines having A1 cytoplasm. The population from which line 1901 was selected has since been released and registered as NP25 low-dhurrin sudangrass germplasm (12). Line 1904 was selected from a population with most of its background from 'Piper'. Both 1901 and 1904 are very low in seedling HCN. p compared to commercially available sudangrasses, and they are considered to be homozygous for low HCN-p. The two grain sorghums used were 'Redlan' and 'Combine Kafir 60' (CK60). A-lines (A1 cytoplasm) and B-lines of these cultivars have been maintained for at least $10 \mathrm{yr}$ by making paired crosses annually to produce A-line seed and also selfing the B-line plants used in the A-line crosses. The lines are considered to be homozygous for high seedling HCN-p.

All possible crosses, including reciprocals, were made among the four parental lines. Crosses were made using gms plants from the sudangrass lines and $\mathrm{cms}$ plants from the sorghum cultivars as females. Use of these male-sterile plants allowed for production of a large number of $F_{1}$ seeds with minimal risk of contamination during crossing. The $F_{1}$ plants were selfed to produce $F_{2}$ seed, and were also used as pollen sources in backcrosses to gms sudangrass and cms sorghum parental plants. To get backcross seed from the sorghum $X$ sorghum $F_{1}$ 's, the $\mathrm{cms}$ hybrids were used as females, and pollen was taken from the parental sorghum B-lines. All crosses were made at the University of Nebraska Agronomy Farm, Lincoln, NE, in the summers of 1982 and 1983 or in the greenhouse in early 1984 . All seedlings analyzed in the laboratory were grown from seed produced either in the field in 1983 or in the greenhouse in early 1984. In total, 52 entries were assayed in the laboratory, including $12 \mathrm{~F}_{1}$ 's, $10 \mathrm{~F}_{2}$ 's, 24 backcrosses, and 6 parental lines (1901, 1904, ARedlan, BRedlan, ACK60, and BCK60).

Twenty-five seed packets were prepared for each of the 52 
entries. Samples of 15 seeds for each parent and $F_{1}$ and 20 seeds for each $F_{2}$ and backcross were counted, weighed, and placed in separate packets. Seeds produced on sorghum females were free of glumes, but many of the seeds produced on sudangrass females were enclosed in glumes. These glumes were removed in all instances before caryopses were weighed and planted.

All entries were chamber-grown in a randomized complete block design. Planting procedures, seedling culturing, and assays of first leaves of week-old seedlings for HCN-p were essentially as described by Gorz et al. (8). One packet of seed from each entry was included in each of 25 separate plantings, giving 25 replications of the experiment. Two seedlings per replication were assayed for each parental line and $F_{1}$, four for each backcross, and six for each $F_{2}$. This gave a total for the whole experiment of 50 seedlings for each parent and $F_{1}, 100$ for each backcross, and 150 for each $F_{2}$. Sampling in this manner allowed for a greater number of seedlings to be assayed from the segregating generations.

Means and standard errors were computed for each entry by pooling data from the 25 replications. Numbers of seedlings assayed were not equal for all entries as described above; therefore, for each of the 52 entries, means were calculated within each replication, and these means were used in all analyses of variance.

To determine the types of gene effects important in the expression of each trait, generation means analysis was computed by the procedure proposed by Gardner and Eberhart (7). Unweighted data from all entries were analyzed as a diallel set of crosses, and a term was included to test for reciprocal effects (11). Deviations from this model provide an estimate of dominance types of epistasis (7). The relative importance among the genetic effects was determined by dividing the sum of squares for each genetic effect from the generation means analysis by the total sum of squares for all entries involved from the analysis of variance. This calculation gave the fraction of the total variation among entries due to each genetic effect for each trait. These fractions were multiplied by 100 and reported as percentages of the total sum of squares for each genetic effect.

Heritability estimates in the narrow sense were calculated by the method described by Warner (19) and in the broad sense by Burton's method (3). Phenotypic and genotypic correlations between traits across all entries were determined by using mean squares and variance components from the analyses of variance and covariance as described by Falconer (5). Phenotypic correlations were calculated between seed weight and $\mathrm{HCN}$-p for each entry, each generation, and groups of entries within each generation.

\section{RESULTS AND DISCUSSION}

Analysis of variance revealed highly significant differences among entries for both seed weight and seedling HCN-p. Results for the six entries for which seed was produced in the greenhouse did not diverge appreciably from those obtained with field-grown seed; therefore, data obtained with greenhouse- and fieldproduced seed are considered together.

Seed weights for the sudangrass lines averaged no more than about one-half, and HCN-p values about one-fourth, of the corresponding values for the sorghum parental lines (Table 1). Sudangrass $X$ sudangrass $F_{1}$ 's and $F_{2}$ 's, and backcrosses of the $F_{1}$ 's to sudangrass parents were generally similar in both seed weight and HCN-p to the sudangrass parents. Also, sorghum $X$ sorghum $F_{1}$ 's and backcrosses of these $F_{1}$ 's to the sorghum parents were similar to the parental lines in seed weight and $\mathrm{HCN}$-p.

Reciprocal crosses between sudangrass and sorghum produced $F_{1}$ seed that weighed about the same as seed of the female parents in the crosses (Table 1). Seedling HCN-p values for these $F_{1}$ 's were intermediate between parental values, and means for sudangrass $X$ sorghum $F_{1}$ 's averaged $72 \%$ as high as those for

Table 1. Minimum and maximum entry means for seed weight and seedling hydrocyanic acid potential (HCN-p).

\begin{tabular}{|c|c|c|c|c|c|c|c|}
\hline \multirow[b]{2}{*}{ Entry group } & \multirow{2}{*}{$\begin{array}{l}\text { No. of } \\
\text { entries }\end{array}$} & \multicolumn{3}{|c|}{ Seed weight } & \multicolumn{3}{|c|}{ HCN-p } \\
\hline & & Min. & Max. & $\operatorname{LSD}(0.05)$ & Min. & Max. & LSD(0.05) \\
\hline & & - & $g$ seed $^{-1}$ & - & $\ldots$ & $\mathrm{ng} \mathrm{kg}^{-1}$ & - \\
\hline Sudangrass parents & 2 & 9.5 & 10.7 & 0.4 & 249 & 263 & 39 \\
\hline Sorghum parents & 4 & 19.3 & 30.6 & 0.2 & 1120 & 1340 & 76 \\
\hline \multicolumn{8}{|l|}{$\mathrm{F}_{1}^{\prime} \mathrm{s}$} \\
\hline Sudan $\times$ sudan & 2 & 9.1 & 10.8 & & 274 & 275 & \\
\hline Sudan $\times$ sorghum & 4 & 11.4 & 12.8 & & 488 & 556 & \\
\hline Sorghum $\times$ sudan & 4 & 22.9 & 26.5 & & 643 & 777 & \\
\hline \multirow[t]{2}{*}{ Sorghum $\times$ sorghum } & $\underline{2}$ & 23.4 & 28.8 & & 1208 & 1306 & \\
\hline & 12 & & & 0.5 & & & 57 \\
\hline \multicolumn{8}{|l|}{ F's } \\
\hline Sudan $\times$ sudan & 2 & 10.1 & 10.9 & & 238 & 255 & \\
\hline Sudan $\times$ sorghum & 4 & 16.1 & 19.9 & & 537 & 616 & \\
\hline \multirow[t]{2}{*}{ Sorghum $\times$ sudan } & $\underline{4}$ & 15.4 & 17.8 & & 5อง & 568 & \\
\hline & 10 & & & 0.6 & & & 37 \\
\hline \multicolumn{8}{|l|}{ Backcrosses to sudangrass } \\
\hline Sudan (sudan $\times$ sudan) & 4 & 9.5 & 11.8 & & 274 & 326 & \\
\hline Sudan (sudan $\times$ sorghum) & 4 & 10.5 & 13.5 & & 402 & 423 & \\
\hline \multirow[t]{2}{*}{ Sudan (sorghum $\times$ sudan) } & $\underline{4}$ & 9.8 & 13.7 & & 380 & 415 & \\
\hline & 12 & & & 0.3 & & & 38 \\
\hline \multicolumn{8}{|l|}{ Backcrosses to sorghum } \\
\hline Sorghum (sudan $\times$ sorghum) & 4 & 20.6 & 32.5 & & 847 & 985 & \\
\hline Sorghum (sorghum $\times$ sudan) & 4 & 20.8 & 27.7 & & 876 & 991 & \\
\hline \multirow[t]{2}{*}{ (Sorghum $\times$ sorghum) sorghum } & $\underline{4}$ & 22.3 & 25.0 & & 1155 & 1222 & \\
\hline & 12 & & & 0.6 & & & 63 \\
\hline
\end{tabular}

†Fresh weight basis. 
Table 2. Mean squares and relative sums of squares for genetic effects from the Gardner and Eberhart (7) generation means analysis.

\begin{tabular}{|c|c|c|c|c|c|}
\hline \multirow[b]{2}{*}{ Source } & \multirow[b]{2}{*}{ df } & \multicolumn{2}{|c|}{ Seed weight } & \multicolumn{2}{|c|}{ HCN-p } \\
\hline & & $\begin{array}{l}\text { Mean } \\
\text { square }\end{array}$ & $\begin{array}{l}\text { Sum of } \\
\text { squares } \dagger\end{array}$ & $\begin{array}{l}\text { Mean } \\
\text { square }\end{array}$ & $\begin{array}{l}\text { Sum of } \\
\text { squares } \dagger\end{array}$ \\
\hline & & & $\%$ & & $\%$ \\
\hline $\begin{array}{l}\text { Entry } \\
\quad a \ddagger \\
h j j^{\prime} \\
a a j j^{\prime} \\
r j j^{\prime} \\
\text { Deviation } \\
\text { Error }\end{array}$ & $\begin{array}{r}51 \\
3 \\
6 \\
6 \\
6 \\
30 \\
1224\end{array}$ & $\begin{array}{c}1087.8^{* *} \\
9791.5^{* *} \\
1400.8^{* *} \\
252.3^{*} \\
314.2^{* *} \\
476.6^{* *} \\
1.0\end{array}$ & $\begin{array}{c}100 \\
53.0 \\
15.2 \\
2.7 \\
3.4 \\
25.7\end{array}$ & $\begin{array}{r}2921469^{* *} \\
36948846^{* *} \\
3709456^{* *} \\
636593^{* *} \\
87307^{* *} \\
384943^{* *} \\
9302\end{array}$ & $\begin{array}{r}100 \\
74.0 \\
15.0 \\
2.6 \\
0.4 \\
8.0\end{array}$ \\
\hline
\end{tabular}

** Significant at the 0.01 level of probability.

† Reported as percentages of the total sum of squares for entry.

$\ddagger a=$ the additive effects due to the $j$ th or $j^{\prime}$ th parental line; $h j j^{\prime}=$ dominance due to the heterosis effect of the $j$ th and $j$ 'th parental lines; aajj' = the additive by additive interaction effect of the $j$ th and $j^{\prime}$ th parental lines; $r j j^{\prime}=$ the reciprocal effect when the $j$ th or $j^{\prime}$ th parental line is used as male or female in a cross.

sorghum $X$ sudangrass $F_{1}$ 's. These differences between reciprocal crosses did not extend into the $F_{2}$ generation; thus, it appears that cytoplasmic inheritance was not involved in the differences observed between reciprocal $F_{1}$ 's.

Backcrosses of the sudangrass $X$ sorghum and sorghum $\times$ sudangrass $F_{1}$ 's produced seed generally similar in size to that of the seed parent in the backcross (Table 1). The HCN-p values for seedlings from backcrosses of these $F_{1}$ 's to the sudangrass parents were somewhat higher than those of the sudangrass lines. Values for seedlings from backcrosses to the sorghum parents were lower than those for the sorghum parental lines and at least twice as high as those for backcrosses to the sudangrass lines.

The pronounced effect of the female parent on $F_{1}$ and backcross seed weight may be due in part to the fact that in the triploid endosperm tissue, two of the three chromosome sets are furnished by the female parent. The pericarp, which is composed of maternal tissue, and the metabolic and transport capabilities of the maternal parent might also influence the size of the caryopsis. Larger seeds should provide correspondingly larger supplies of precursors for dhurrin synthesis, which might help to account for the observed effect of the maternal parent on $\mathrm{HCN}$-p values in the $F_{1}$ and backcross generations. As will be seen, however, seed weight and $\mathrm{HCN}$-p were not always closely related to each other.

Frequency distributions of seed weight and $\mathrm{HCN}-\mathrm{p}$ for the $F_{2}$ and backcross generations of the crosses between sorghum and sudangrass did not indicate a clear separation of the progenies into a small number of discrete classes (15). Both traits, therefore, appeared to be inherited quantitatively. The $F_{1}$ and $F_{2} H C N-p$ distributions, and also $F_{1}$ and $F_{2}$ mean $H C N-p$ values, were somewhat skewed in the direction of the sudangrass parents, suggesting that in these crosses low $\mathrm{HCN}$ $\mathrm{p}$ was partially dominant to high $\mathrm{HCN}-\mathrm{p}$.

Variation among entries was used in generation means analysis (7) to ascertain the types of genetic effects that controlled seed weight and $\mathrm{HCN}-\mathrm{p}$ (Table 2 ). Additive genetic effects accounted for $53 \%$ of the variation for seed weight among entries and genera- tions. Dominance effects and deviations from the model (dominance types of epistasis) accounted for much of the remaining variation. Voigt et al. (18), investigating the inheritance of seed size in crosses between small- and large-seeded sorghum varieties, found that additive effects accounted for almost all of the variation among generations. Dominance effects were significant in that study also, but accounted for a very small fraction of the variation among generations. Dominance effects and epistasis seemed to play a greater role in the present study.

Additive genetic effects accounted for $74 \%$ of the variation for $\mathrm{HCN}-\mathrm{p}$ among lines and generations (Table 2). The preponderance of additive genetic effects for HCN-p agrees with the findings of Boora and Lodhi (2). Dominance effects accounted for at least half of the remaining variation. Reciprocal effects also were significant for both seed weight and HCN-p, but the fraction of variation attributable to these effects was relatively small (Table 2 ). A reciprocal effect for $\mathrm{HCN}$ $p$ in the $F_{1}$ hybrids was not reported in previous studies. This was probably due to the fact that in most of these studies, either high- or low-HCN-p lines were used consistently as the seed parent (17). Other studies $(6,10)$ investigated tillers and mature leaves of reciprocal $F_{1}$ hybrids but did not reveal a maternal effect on HCN-p. Numerous reports have indicated that HCN-p can be strongly influenced by stage of growth and plant part (e.g., 1, 13, 16). Haskins et al. (13) showed significant positive correlations between seedling and tiller HCN-p. However, it is doubtful that the maternal effect found in week-old seedlings would persist in plant tillers.

Broad- and narrow-sense heritability estimates for HCN-p were 0.60 and 0.42 , respectively. Seed weight was recorded only as a mean seed weight per replication; no within-plot error was measured. Therefore, calculations of heritability estimates for seed weight using these methods were not possible in the present study. Heritability estimates for HCN-p probably were maximized by the wide differences in this trait in the chosen parental lines. The observed estimates suggest that progress could be made in breeding for high or low levels of HCN-p. The difference between broadsense and narrow-sense heritability estimates indicated the importance of nonadditive genetic effects for HCN-p and was in agreement with results previously reported by Gorz et al. (9). Additive $X$ additive epistatic effects for $\mathrm{HCN}$-p were very small in comparison with additive effects (Table 2); therefore, the narrow-sense heritability estimate calculated by Warner's method (19) was not greatly biased.

Phenotypic and genotypic correlations between seed weight and $\mathrm{HCN}-\mathrm{p}$ across all entries were $0.85^{* *}$ and 0.86 , respectively. These correlations reflect the fact that entries with larger seed generally had greater seedling $\mathrm{HCN}-\mathrm{p}$. To investigate further the relationship between seed weight and $\mathrm{HCN}-\mathrm{p}$, simple correlations between these two traits were calculated for each entry, each generation, and for groups of crosses within each generation. No consistent correlation between seed weight and HCN-p was observed within individual entries. The $52 r$ values ranged from -0.50 to +0.59 , and only four were statistically significant. There was 
Table 3. Simple correlations between seed weight and hydrocyanic acid potential.

\begin{tabular}{lcc}
\hline Entries & $n$ & $r$ \\
\hline All parental lines & 150 & $0.82^{* *}$ \\
Sudangrass parents & 50 & $0.31^{*}$ \\
Sorghum parents & 100 & -0.07 \\
Reciprocal $F_{1}^{\prime}$ 's & 200 & $0.69^{* *}$ \\
Sudangrass as seed parent & 100 & -0.19 \\
Sorghum as seed parent & 100 & -0.08 \\
Reciprocal $F_{2}$ 's & 200 & 0.11 \\
Sudangrass as seed parent in $F_{1}$ & 100 & $0.31^{* *}$ \\
Sorghum as seed parent in $F_{1}$ & 100 & -0.11 \\
Backcrosses to either sudangrass or sorghum & 400 & $0.85^{* *}$ \\
Backcrosses to sudangrass & 200 & 0.05 \\
Backcrosses to sorghum & 200 & 0.08 \\
\hline *** Significant at the 0.05 and 0.01 levels of probability, respectively.
\end{tabular}

a significant positive correlation between seed weight and $\mathrm{HCN}$-p across all parents (Table 3). This correlation was probably due mainly to the fact that the sudangrass parents, chosen for their low HCN-p, had small seeds while the sorghum parents, chosen for their high HCN-p, had large seeds. No correlation was demonstrated among the sorghum parents, and a significant but low correlation was found among the sudangrass parents, indicating that seed weight had little if any effect on HCN-p within each of the parental types. Significant positive correlations between seed weight and $\mathrm{HCN}-\mathrm{p}$ were found for all $\mathrm{F}_{1}$ 's considered together and for all backcrosses considered together. However, no significant correlations between seed weight and HCN-p were demonstrated within $F_{1}$ 's with either sorghum or sudangrass as the seed parent, or in backcrosses to either sorghum or sudangrass alone. Also, no significant relationships between seed weight and seedling $\mathrm{HCN}-\mathrm{p}$ was indicated by the pooled $\mathrm{F}_{2}$ data.

In an expanded investigation of the possible relationship of seed size and seedling HCN-p, Lamb (15) used the same six parental lines and eight sorghumsudangrass $F_{1}$ 's that were used in the present study. Large and small seeds were selected for each of the 14 entries, and seedling $\mathrm{HCN}$-p values were determined. As in the present study, no significant correlation between seed weight and seedling $\mathrm{HCN}-\mathrm{p}$ within entries was found. When seeds are identical with respect to the genotypes of both endosperm and embryo, seed weight appears to have little if any relationship to seedling $\mathrm{HCN}$-p.

In summary, quantitative inheritance patterns were observed for both seed weight and seedling HCN-p in crosses between low-HCN-p, small-seeded sudangrasses and high-HCN-p, large-seeded sorghums. Generation means analysis indicated that additive genetic effects were most important in influencing both seed weight and seedling HCN-p. A maternal effect was observed for both traits in the $F_{1}$ and backcross generations, but not in the $F_{2}$ generation. Seed weight per se appeared not to have a large effect on seedling $\mathrm{HCN}$ p.

\section{ACKNOWLEDGMENT}

The excellent technical assistance of Carol A. Caha is gratefully acknowledged.

\section{REFERENCES}

1. Acharya, C.N. 1933. Investigations on the development of prussic acid in cholam (Sorghum vulgare). Ind. J. Agric. Sci. 3:851869.

2. Boora, K.S., and G.P. Lodhi. 1982. Combining ability for toxic constituents in forage sorghum. Ind. J. Agric. Sci. 52:211-214.

3. Burton, G.W. 1952. Quantitative inheritance in grasses In Proc. Int. Grassl. Congr. 6th, 1952:277-283.

4. Eck, H.V., E.C. Gilmore, D.B. Ferguson, and G.C. Wilson. 1975. Heritability of nitrate reductase and cyanide levels in seedlings of grain sorghum cultivars. Crop Sci. 15:421-424.

5. Falconer, D.S. 1981. Introduction to quantitative genetics. 2nd ed. Longman Inc., New York.

6. Franzke, C.J., L.F. Puhr, and A.N. Hume. 1939. A study of sorghum with reference to the content of HCN. South Dakota Agric. Exp. Stn. Tech. Bull. 1.

7. Gardner, C.O., and S.A. Eberhart. 1966. Analysis and interpretation of the variety cross diallel and related populations. Biometrics 22:439-452.

8. Gorz, H.J., W.L. Haag, J.E. Specht, and F.A. Haskins. 1977. Assay of $p$-hydroxybenzaldehyde as a measure of hydrocyanic acid potential in sorghums. Crop Sci. 17:578-582.

9. --, F.A. Haskins, and K.P. Vogel. 1982. Divergent selection for hydrocyanic acid potential in sudangrass. Crop Sci. 22:322325.

10. ---, ---, and --.- 1986. Inheritance of dhurrin content in mature sorghum leaves. Crop Sci. 26:65-67.

11. Griffing, B. 1956. Concept of general and specific combining ability in relation to diallel crossing systems. Aust. J. Biol. Sci. $9: 463-493$

12. Haskins, F.A., H.J. Gorz, S.D. Kindler, S.G. Jensen, and A. Sotomayor-Rios. 1986. Registration of NP25 low-dhurrin sudangrass germplasm. Crop Sci. 26:213.

13. - - - - , and R.L. Nielsen. 1979. Comparison of the hydrocyanic acid potential of Sorghum seedlings and tillers. Agron. J. 71:501-504.

14. Krauss, M. 1971. Die Vererbung des Blausäuregehaltes bei Sorghum [Sorghum bicolor (L.) Moench]. Z. Pflanzenzüchtg. 66:301-311.

15. Lamb, J.F.S. 1985. Inheritance of seedling hydrocyanic acid potential and other traits in sorghum-sudangrass crosses. Ph.D. diss. Univ. of Nebraska, Lincoln (Diss. Abstr. 85-26597).

16. Loyd, R.C., and E. Gray. 1970. Amount and distribution of hydrocyanic acid potential during the life cycle of plants of three sorghum cultivars. Agron. J. 62:394-397.

17. Nass, H.G. 1972. Cyanogenesis: Its inheritance in Sorghum bicolor, Sorghum sudanense, Lotus, and Trifolium repens-a review. Crop Sci. 12:503-506.

18. Voigt, R.L., C.O. Gardner, and O.J. Webster. 1966. Inheritance of seed size in sorghum, Sorghum vulgare Pers. Crop Sci. 6:582586.

19. Warner, J.N. 1952. A method for estimating heritability. Agron. J. 44:427-430. 